\title{
PENINGKATAN KEMAMPUAN PEMECAHAN MASALAH PESERTA DIDIK DENGAN PENERAPAN MODEL PEMBELAJARAN PROBLEM POSSING
}

\author{
Arlin Astriyani \\ Universitas Muhammadiyah Jakarta \\ arlin_0717@yahoo.com
}

\begin{abstract}
Abstrak
Penelitian bertujuan untuk menganalisis penerapan model pembelajaran Problem Posing dalam meningkatkan kreativitas belajar peserta didik dalam menyelesaikan masalah. Penelitian ini dilakukan di Program Studi Pendidikan Matematika Universitas Muhammadiyah Jakarta mata kuliah Geometri Euclid pada tahun ajaran 2014/2015. Metode yang digunakan dalam penelitian ini adalah Penelitian Tindakan Kelas (PTK) yang dilaksanakan dalam dua siklus. Instrumen penelitian yang digunakan adalah lembar observasi, jurnal harian peserta didik, pedoman wawancara, tes pemecahan masalah matematika, dan dokumentasi.

Hasil penelitian mengungkapkan bahwa penerapan model pembelajaran Problem Posing dapat meningkatkan kemampuan pemecahan masalah matematika peserta didik. Pada siklus I nilai rata-rata kemampuan pemecahan masalah matematika peserta didik 72 meningkat 9 menjadi 81 pada siklus II. Selain kemampuan pemecahan masalah, aktivitas belajar peserta didik dan respon peserta didik menunjukkan peningkatan. Rata-rata aktivitas belajar peserta didik pada siklus I sebesar $63,5 \%$ dan meningkat $11,1 \%$ pada siklus II menjadi 74,6\%. Berdasarkan jurnal harian, rata-rata persentase respon positif peserta didik mengalami peningkatan, yaitu pada siklus I sebesar $57,2 \%$ meningkat $14,2 \%$ menjadi $71,4 \%$ pada siklus II.
\end{abstract}

Kata kunci: Pemecahan Masalah Matematika, Problem Possing

\section{PENDAHULUAN}

Pendidikan merupakan bagian penting yang tidak dapat dipisahkan dalam kehidupan. Pendidikan menjadi kebutuhan primer bagi manusia yang dapat mengantarkannya menjadi masyarakat terdidik dan cerdas yang dapat memajukan bangsa. Matematika merupakan ilmu universal yang mendasari perkembangan teknologi modern, mempunyai peran penting dalam berbagai disiplin dan memajukan daya pikir manusia. Perkembangan pesat di bidang teknologi informasi dan komunikasi dewasa ini dilandasi oleh perkembangan matematika di 
bidang teori bilangan, aljabar, analisis, teori peluang, dan matematika diskrit. Karena itu, untuk menguasai dan memanfaatkan teknologi di masa depan diperlukan penguasaan matematika yang kuat sejak dini. Tujuan pembelajaran matematika tidak hanya dimaksudkan agar peserta didik terampil melakukan operasi penjumlahan, pengurangan, perkalian dan pembagian, tetapi juga untuk mengusahakan agar peserta didik mampu menggunakan keterampilan tersebut untuk menyelesaikan masalah.

Proses belajar mengajar matematika di kelas digunakan pendekatan alternatif yang membuat peserta didik berkesempatan untuk mengajukan masalah. Selain itu, penting untuk tenaga pendidik mengajarkan kemampuan memecahkan masalah sehingga dapat mengantarkan peserta didik mengalami kesuksesan di masa depan dengan menjadi pemecah masalah yang efektif. Dalam proses pembelajaran di kelas, diharapkan tenaga pendidik dapat menerapkan model pembelajaran yang sesuai dengan materi dan dapat membuat peserta didik berperan aktif dalam kegiatan belajar mengajar di kelas. Model pembelajaran yang dapat digunakan sala satunya yaitu Problem Posing.

Rumusan masalah penelitian ini adalah:

1. Apakah penerapan model Problem Posing dapat meningkatkan kemapuan pemecahan masalah matematika peserta didik?

2. Bagaimanakah aktivitas belajar matematika peserta didik selama penerapan model Problem Possing?

3. Bagaimanakah tanggapan peserta didik selama penerapan model Problem Possing?

\section{KAJIAN PUSTAKA}

Pemecahan masalah merupakan kompetensi strategi yang ditunjukkan peserta didik dalam memahami, memilih pedekatan dan strategi pemecahan masalah, menggunakan model untuk menyelesaikan masalah. Indikator yang menunjukkan pemecahan masalah, antara lain:

1. Menunjukkan pemecahan masalah.

2. Mengoordinasi data dan memilih informasi yang relevan dalam pemcahan masalah.

3. Menyajikan masalah secara matematika dalam berbagai bentuk.

4. Memilih pendekatan dan metode pemcahan masalah secara tepat.

5. Mengembangkan strategi pemecahan maalah.

6. Membuat dan menafsirkan model matematika dari suatu masalah.

7. Menyelesaikan masalah yang tidak rutin. (Shadiq, 2009: 14) 
Polya (dalam Wardhani, 2008: 33 - 34) menyatakan secara rinci empat langkah penyelesaian pemecahan masalah matematika, yaitu:

1. Memahami masalah

Langkah ini melibatkan pendalaman situasi masalah, melakukan pemilihan faktafakta, menentukan hubungan diantara fakta-fakta dan membuat formulasi pertanyaan masalah.

2. Membuat rencana pemecahan masalah

Langkah ini perlu dilakukan dengan percaya diri ketika masalah sudah dapat dipahami. Rencana solusi dibangun dengan mempertimbangkan struktur masalah dan pertanyaan yang harus dijawab.

3. Melaksanakan rencana pemecahan masalah

Untuk mencari solusi yang tepat, rencana yang sudah dibuat pada langkah 2 harus dilaksanakan dengan hati-hati.

4. Melihat (mengecek) kembali

Selama langkah ini berlangsung, solusi masalah harus dipertimbangkan. Perhitungan yang dilakukan harus dicek kembali. Melakukan pengecekan dapat melibatkan pemecahan masalah yang mendeterminasi akurasi dari komputasi dengan menghitung ulang. Jika kita membuat estimasi, maka harus dibandingkan dengan solusinya.

Model pembelajaran Problem Posing menurut Silver, dkk (dalam Siswono, 2008: 41) sebagai perumusan soal sederhana atau perumusan ulang soal yang ada dengan beberapa perubahan agar lebih sederhana dan dapat dikuasai, yang terjadi dalam pemecahan masalah soal-soal yang rumit. Model pembelajaran ini menitikberatkan pada pemecahan masalah, peserta didik diajak untuk aktif sehingga informasi tidak hanya dari tenaga pendidik, tetapi peserta didik juga dituntut untuk mengkonstruksi sendiri pengetahuan baru mereka dengan informasi atau pengetahuan mereka sebelumny. Xia, dkk. (2008: 154) juga menyatakan bahwa pembelajaran yang melibatkan aktivitas Problem Posing dapat menimbulkan ketertarikan peserta didik terhadap matematika, meningkatkan kemampuan mereka dalam mengajukan masalah dan meningkatkan kemampuan belajar matematika mereka dengan baik. Di sisi lain, Cankoy, dkk (2010:12) dalam penelitiannya menyimpulkan bahwa peserta didik yang diberikan pembelajaran Problem Posing dapat menyelesaikan tes pemahaman masalah dengan baik. Problem Posing merupakan model pembelajaran yang mengharuskan pertanyaan-pertanyaan yang lebih sederhana yang mengacu pada penyelesaian soal tersebut. 
Problem Posing dapat diartikan membangun atau membentuk permasalahan. Problem Posing adalah suatu kegiatan pemberian tugas kepada peserta didik agar terlibat langsung dalam pembuatan soal dan menyelesaikannya sesuai dengan konsep atau materi yang telah dipelajari. Pengertian Problem Posing tidak terbatas pada pembentukan soal yang betul-betul baru, tetapi dapat berarti mereformulasi soal-soal yang diberikan.

Menurut Silver, dkk (dalam Siswono, 2008: 41), Problem Posing meliputi beberapa pengertian, yaitu:

1. Perumusan soal sederhana atau perumusan ulang soal yang ada dengan beberapa perubahan agar lebih sederhana dan dapat dikuasai,

2. Perumusan soal yang berkaitan dengan syarat-syarat pada soal yang telah dipecahkan dalam rangka pencarian alternatif penyelesaian atau alternatif soal yang relevan, dan

3. Perumusan soal atau pembentukan soal dari suatu situasi yang tersedia, baik dilakukan sebelum, ketika atau setelah pemecahan suatu soal/masalah.

Problem Posing atau pembentukan soal atau pembentukan masalah mencakup dua macam kegiatan, yaitu:

1. Pembentukan soal baru atau pembentukan soal dari situasi atau dari pengalaman peserta didik.

2. Pembentukan soal dari soal yang sudah ada.

Sedangkan Silver dan Cai (dalam Muhammad Thobroni, 2011:352) mengklasifikasikan tiga aktivitas koginitif dalam pembuatan soal sebagai berikut.

1. Pre-solution posing, yaitu pembuatan soal berdasarkan situasi atau informasi yang diberikan.

2. Within-solution posing, yaitu pembuatan atau formulasi soal yang sedang diselesaikan. Pembuatan soal demikian dimaksudkan sebagai penyederhanaan dari soal yang sedang diselesaikan. Dengan demikian, pembuatan soal akan mendukung penyelesaian soal semula.

3. Post-Solution Posing. Strategi ini juga disebut sebagai strategi "find a more challenging problem". Peserta didik memodifikasi atau merevisi tujuan atau kondisi soal yang telah diselesaikan untuk menghasilkan soal-soal baru yang lebih menantang. Pembuatan soal demikian merujuk pada strategi "what-if-not ...?" atau "what happen if ...". 
Pembelajaran dengan model Problem Posing biasanya diawali dengan penyampaian teori atau konsep. Penyampaian materi menggunakan metode ekspositori, setelah itu, pemberian contoh soal dan pembahasannya. Selanjutnya, pemberian contoh membuat masalah dari masalah yang ada dan menjawabnya, kemudian peserta didik diminta belajar dengan Problem Posing. Mereka diberi kesempatan belajar individu atau berkelompok. Setelah pemberian contoh cara membuat masalah, peserta didik tidak perlu lagi diberikan contoh. Penerapan dan penilaian yang cukup sederhana dari model ini, yaitu dengan cara peserta didik diminta mengajukan soal yang sejenis atau setara dari soal yang telah dibahas. Dengan cara ini kita bisa melihat sejauh mana daya serap peserta didik terhadap materi yang baru saja diberikan. Pada prinsipnya, model pembelajaran Problem Posing adalah suatu model pembelajaran yang mewajibkan para peserta didik untuk mengajukan soal sendiri melalui belajar soal (berlatih soal) secara mandiri. Secara garis besar, pembelajaran Problem Posing sebagai berikut:

1. Menyiapkan pembelajaran

2. Menjelaskan tujuan pembelajaran

3. Menjelaskan materi pembelajaran

4. Memberikan contoh membuat soal

5. Memberikan kesempatan kepada peserta didik untuk menanyakan yang belum jelas.

6. Memberikan kesempatan kepada peserta didik untuk membuat soal sebanyak mungkin dari situasi yang diberikan dan mempresentasikannnya di depan kelas.

7. Mempersilahkan peserta didik menyelesaikan soal yang dibuatnya sendiri.

8. Sebagai latihan, tenaga pendidik memberikan situasi yang lain dan meminta peserta didik membuat soal lagi

9. Mempersilahkan peserta didik untuk menyelesaikan soal yang dibuatnya.

\section{METODE PENELITIAN}

Metode penelitian yang digunakan dalam penelitian ini adalah penelitian tindakan kelas, yaitu suatu pencermatan terhadap kegiatan belajar berupa sebuah tindakan yang sengaja dimunculkan dan terjadi dalam sebuah kelas secara bersama (Arikunto, 2007: 3). Metode penelitian tindakan kelas berusaha mengkaji dan merefleksi suatu pendekatan atau strategi pembelajaran dengan tujuan untuk meningkatan proses dan produk pelajaran di kelas. 


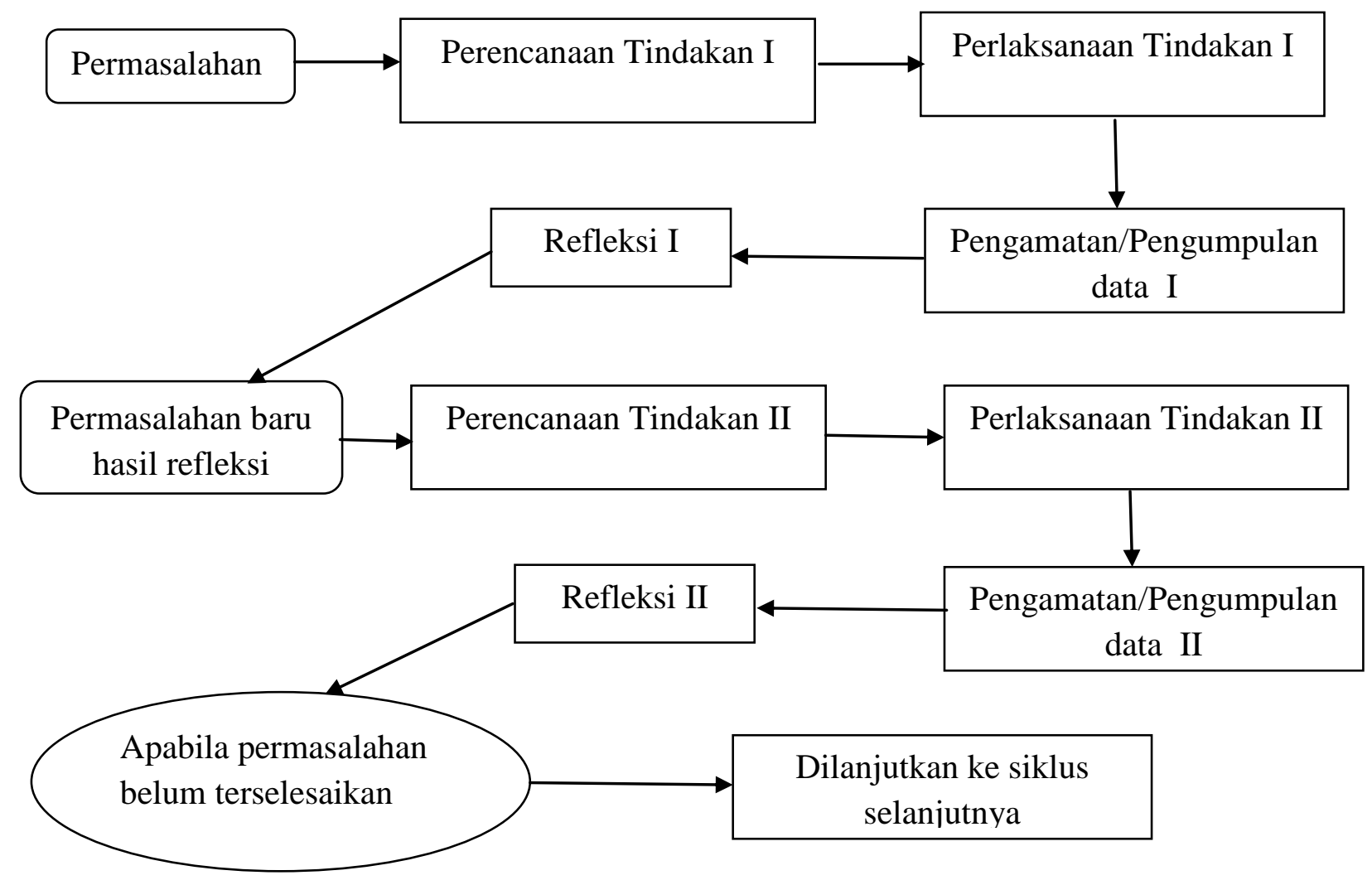

Gambar 1. Desain Penelitian Tindakan Kelas

Penelitian ini dilaksanakan di Program Studi Pendidikan Matematika, Fakultas Ilmu Pendidikan, Universitas Muhammadiyah Jakarta. Penelitian ini dilakukan pada mahasiswa didik semester I mata kuliah Geometri Euclid tahun pelajaran 2014/2015.

Hasil penelitian yang diharapakan dalam penelitian ini adalah meningkatnya kemampuan pemecahan masalah matematika peserta didik. Penelitian ini akan dihentikan jika:

1. Hasil tes kemampuan pemecahan masalah matematika peserta didik yang diberikan pada setiap akhir siklus menujukkan bahwa nilai rata-rata peserta didik mencapai $\geq 70$.

2. Aktivitas pembelajaran peserta didik $\geq 70 \%$.

3. Minimal $70 \%$ dari seluruh peserta didik merespon positif pembelajaran matematika.

\section{HASIL DAN PEMBAHASAN}

Peningkatan kemampuan pemecahan masalah matematika terlihat dari meningkatnya hasil kemampuan pemecahan masalah dari siklus I ke siklus II. Rata-rata nilai peserta didik meningkat 9,0. Pada siklus I nilai rata-rata kemampuan pemecahan masalah matematika peserta didik 72 meningkat menjadi 81 pada siklus II. Hasil jawaban peserta didik menunjukkan bahwa kemampuan pemecahan masalah meliputi kemampuan memahami 
masalah, menyusun rencana melakukan perhitungan dan menguji kembali dapat dilakukan cukup baik oleh peserta didik. Berdasarkan peningkatan yang terjadi dan hasil kemapuan pemecahan masalah yang diperoleh peserta didik, dapat disimpulkan bahwa penerapan model Problem Posing dapat meningkatkan kemampuan pemecahan masalah peserta didik.

Skor rata-rata lembar aktivitas kelompok pada siklus I sebesar 63,5\%. Aspek yang memperoleh skor terendah pada siklus I adalah kemampuan bertukar pikiran. Pada siklus II aktivitas ini meningkat diikuti peningkatan aktivitas-aktivitas lainnya. Skor rata-rata aktivitas kelompok pada siklus II mencapai 74,6\% berdasarkan hasil observasi aktivitas kelompok menunjukkan bahwa penerapan model Problem Posing meningkatkan aktivitas kelompok mahasiswa semester 1 .

Respon peserta didik dikelompokkan menjadi tiga kategori, yaitu positif, negatif dan netral. Berdasarkan analisis jurnal harian peserta didik selama siklus I dan siklus II diperoleh terjadi penurunan respon negatif. Rata-rata persentase respon negatif peserta didik turun dari $21,5 \%$ pada siklus I menjadi 6,7\% pada siklus II, sementara itu respon positif meningkat dari $57,2 \%$ pada siklus I menjadi $74,8 \%$ pada siklus II. Berdasarkan hasil rata-rata persentase respon peserta didik yang terdapat pada jurnal harian peserta didik menunjukkan respon positif terhadap penerapan model Problem Possing.

\section{SIMPULAN DAN SARAN}

Berdasarkan hasil penelitian dan pembahasan, disimpulkan bahwa penerapan model pembelajaran Problem Posing dapat meningkatkan kemampuan pemecahan masalah matematika peserta didik. Pada siklus I nilai rata-rata kemampuan pemecahan masalah matematika peserta didik 72 meningkat 9 menjadi 81 pada siklus II. Selain kemampuan pemecahan masalah, aktivitas belajar peserta didik dan respon peserta didik menunjukkan peningkatan. Rata-rata aktivitas belajar peserta didik pada siklus I sebesar $63,5 \%$ dan meningkat $11,1 \%$ pada siklus II menjadi 74,6\%. Berdasarkan jurnal harian, rata-rata persentase respon positif peserta didik mengalami peningkatan, yaitu pada siklus I sebesar $57,2 \%$ meningkat $14,2 \%$ menjadi $71,4 \%$ pada siklus II.

Berdasarkan simpulan, dikemukakan beberapa saran yaitu bagi calon tenaga pengajar hendaknya termotivasi untuk menerapkan model pembelajaran inovatif supaya mampu mengoptimalkan kemampuan pemecahan masalah peserta didik terhadap suatu konsep matematika. Salah satu model pebelajaran inovatif yang dapat diterapkan untuk mengoptimalkan kemampuan pemecahan masalah peserta didik terhadap konsep matematika adalah model pembelajaran Problem Posing. 


\section{DAFTAR PUSTAKA}

Arikunto, Suharsimi. (2007). Penelitian Tindakan Kelas. Jakarta: PT Bumi Aksara.

Cankoy, O and Darbaz, S. (2010). "Effect or Problem posing Based Problem Solving Instruction on undertsanding Problem". Journal of Education. Vol. 38, pp. 11-24.

Muhammad Thobroni, dkk. (2011). Belajar dan Pembelajaran, Pengembangan Wacana dan Praktik Pembelajaran dalam Pembangunan Nasional. Yogyakarta: Ar Ruz Media.

Shadiq, Fajar. (2009). Kemahiran Matematika. Yogyakarta: Depdiknas.

Siswono, Tatag Yuli Eko. (2008). Model Pembelajaran Matematika Berbasis Pengajuan dan Pemecahan Masalah untuk Meningkatkan Kemampuan Berpikir Kreatif. Surabaya: UNESA University Press.

Wardhani, Sri. (2008). Analisis SI dan SKI, Mata Pelajaran Matematika SMP/MTS untuk Optimalisasi Tujuan Pemelajaran Matematika. Yogyakarta: PPPPTK Matematika.

Xia, X., Lü, C., Wang, B. (2008). "Research on Mathematics Instruction Experi-ment Based Problem Posing”. Journal of Mathematics Education. Vol. 1, pp. 153-165. 